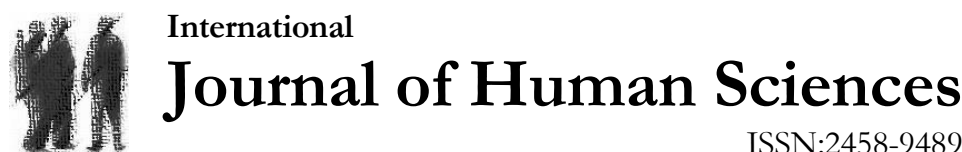

Volume: 18 Issue: 4 Year: 2021

\section{A spatial analysis of the physical properties of Sivas Cumhuriyet University Campus}

\author{
Uğur Tuztaş1 ${ }^{1}$ \\ Pinar Koç
}

\begin{abstract}
Research problem/aim: This study aimed to reveal the physical characteristics of the Sivas Cumhuriyet University Campus. University campuses are equipped with highly diversified physical qualities in terms of the design and planning stages. The quality and property of the physical space are the values that enrich and develop the livable, accessible, and perceptible features of the campus space. In this study, the basic physical components that make up a university campus were identified in order to analyze their qualities. Method: The method was based on fieldwork documentation tools such as observation, on-site examination, photography, and drawing. Accordingly, the Sivas Cumhuriyet University campus was evaluated in terms of its basic physical characteristics such as borders, building usage patterns, morphology, occupancy-vacancy, common areas, and green areas. Findings: It was determined that the campus space has a scattered and disjointed group of relationships, and individual and independent spatial arrangements present a fragmented appearance throughout the built environment. Accordingly, it was determined that the common and green areas and the occupancy-vacancy relations were disturbed, and a morphologically unstable and scattered physical space presentation emerged. Conclusions: Ultimately, this study, which analyzed the current physical environment of the campus, proposed the preparation of an urgent design guide for the campus in order to transform the built environmental components that have been constructed in a disconnected, dispersed, fragmented and unrelated manner into holistic, coherent and continuous spatial organizations.
\end{abstract}

Keywords: Spatial analysis; university campus; campus planning; campus setting; Sivas.

\footnotetext{
1 Assoc. Prof. Dr., Sivas Cumhuriyet University, Faculty of Architecture, Fine Arts and Design, Department of Architecture, ugurtuztasi@gmail.com (iD) Orcid ID: 0000-0003-3668-5665

2 Research Assistant Dr., Sivas Cumhuriyet University, Faculty of Architecture, Fine Arts and Design, Department of Architecture, pinarkoc85@gmail.com (D) Orcid ID: 0000-0001-8727-2655
} 
Tuztașı, U., \& Koç, P. (2021). A spatial analysis of the physical properties of Sivas Cumhuriyet University Campus. Journal of Human Sciences, 18(4), 564-577. doi:10.14687/jhs.v18i4.6123

\subsection{General introduction and review of}

In general terms, university campuses have been examined from many angles in the architectural literature. The most common type of assessment consists of formal examinations that scrutinize the landscape pattern of the campus as a residential area and various changes and developments (Tanriverdi \& Güçlü, 1984; Irgatoğlu, 2011). Recently, new approaches such as mapping the behavior patterns of campus users and revealing user habits have emerged (Düzenli et al., 2017; Yorgancioğlu et. al., 2018). On the other hand, a campus means a university settlement. In addition to the academic and administrative units of a university, a campus can be defined as a spatial organization where facilities such as student dormitories, lodgings, and social-cultural areas are located. In other words, university campuses are urban areas that are isolated from the urban space, formed with a holistic design approach. They often do not have the potential to be reconstructed, and do not reflect the identity of the users but have the potential to create/produce the identity of the users (Gümüş, 2020, 210). Campuses are also described as small city models (Çiçek Kurdoğlu et al., 2018, 2065). While they are generally classified as urban and extra-urban examples, today they are also seen as campus systems, urban university buildings, or building groups that have undergone changes in function. Until the 1950s, the university system was composed of such groups until the individual or discrete structure group moved to large areas outside the city in Turkey in 1950, and, thus, the first campus examples began to emerge in the country (Göçer et al., 2018, 855). Moreover, some campuses have been acquired through architectural project competitions. Karadeniz Technical University in 1955, Middle East Technical University in 1956, and Atatürk University in 1957 can be regarded as the first campus examples in our country (Göçer et al., 2018, 855).

The design and planning stages of a campus within the university system are important. In a campus consisting of different functional units such as education, housing, social, and cultural areas, the relationship between the components can be arranged with various design principles. Thus, various systems have been developed that create systematic order for the campuses, regulate the organization of on-campus functions, and determine the growth style and direction of the campus. Linde, known for his four-volume book Hochschulplannung, which includes all aspects of university planning in 1970, typified universities on the basis of their spatial organization and devoted a great deal of attention to the rationalization of university buildings. According to the systematic approach developed by Linde, campuses can be classified as widespread type, central type, molecular type, network type, cross type, and linear type settlement systems (Büyükşahin Siramkaya \& Çınar, 2012, 63; Sönmezler, 2003, 203, 228). These settlement systems have generally been developed based on the positioning of the structures, transportation axes, open spaces, and other spaces that make up the campus, and each settlement system has different dynamics, problems, and possibilities. In addition to these systems that define the scale and form of campus settlement, nowadays there are new approaches called a "learning landscape" that extend the boundaries of learning from the classroom to the entire campus through space-pedagogy research (Yorgancioğlu et al., 2018, 323). Accordingly, education in different disciplines is provided on university campuses, and it is emphasized that the spaces on the campus should be designed to support methods specific to different disciplines. Moreover, it is essential to construct some specialized fields according to the characteristics of the disciplines in order to provide not only technological infrastructure, but also "learning from the environment" on the campus (Yorgancioğlu et al., 2018, 318-319). This study aims to reveal the physical characteristics of the Sivas Cumhuriyet University Campus and to create a basis of the current situation for possible planning and design activities within the settlement system. For this purpose, firstly the values that constitute the physical characteristics of campus spaces are examined, then brief information about the establishment stages of the Cumhuriyet University is provided and the study concludes with a field study in which the physical properties are revealed. 
Tuztaş1, U., \& Koç, P. (2021). A spatial analysis of the physical properties of Sivas Cumhuriyet University Campus. Journal of Human Sciences, 18(4), 564-577. doi:10.14687/jhs.v18i4.6123

\subsection{A general assessment of the physical properties of campus spaces}

In the planning of a university campus, there is grouping according to the campus size, population, spatial requirements, circulation system and pedestrian scale (entrances, roads, squares, parking lots), organizational structure and functional relations of units (working, accommodation, recreation, transportation function). These are physical qualities and concepts that help design aspects such as on-campus transportation (vehicle, pedestrian), growth and change, flexibility, and adaptability (Ak, 2007, 44-53). The physical components of the campus system consist of items such as education, accommodation, socio-cultural areas, and transportation axes as well as open spaces. Among these, structures in which the university's administrative units are located and functions such as education and research are of primary importance in the campus system. The area defined by these structures is generally called the academic field. This is one of the functions that make up the university city according to the decisions taken in CIAM, and other functions are classified as common areas, accommodation areas, and transportation systems (Irgatoğlu, 2011, 8). Common areas are the most important physical component of the campus for users. These areas can be classified as places that fulfill educational, administrative, and basic needs and places for recreation (Büyükşahin Sıramkaya \& Çınar, 2012, 65). Places that fulfill educational, administrative, and basic needs can be considered as places that are generally located in the academic field and where the management, education, research, application, and accommodation functions of the university are located. All open and closed spatial arrangements in the campus as a resting and recreation area are also part of the common areas. The spaces and functions in these regions offer various opportunities for the establishment and continuity of interdisciplinary relationships (Erçevik \& Önal, 2011, 153). For example, in these areas, daily needs can be met, as well as participation in scientific activities with events such as conferences and symposiums. These areas can be a part of the sports activity or include spatial arrangements for hobby and entertainment purposes.

Open spaces in a campus system can be defined as the spaces surplus from the buildings in the settlement system. This outdoor pattern, which creates spaces with voids within the built environment, appears on the campus in various forms. For example, if structures are positioned around a point that is considered a center, central open areas are formed, and if these areas are open on one side, focused open areas are formed. While narrow and long spaces that are open from both sides are called linear open spaces; organic linear open spaces, on the other hand, are defined as an open space where there is an open order and surprise places are encountered (Düzenli et al., 2017, 768). These open spaces correspond to outdoor spaces in a campus. Outdoor spaces are used for activities such as learning, discovering, examining and researching (Aydin \& Ter, 2008, 191). As well as educational issues, an outdoor space also provides space for outdoor activities. These outdoor activities can be divided into two groups. Passive activities in an outdoor space can be consisted of sitting, enjoying scenery and watching others; these leisure activities need a natural green area in a campus (Lau et al., 2014, 459). Active green areas also provide space for group gatherings, show-stage or open market during special occasions (Lau et al., 2014, 460). In sum, open and green areas in campuses should be addressed through functional expansions such as providing balance at the scale of the built environment single structure, providing space for the circulation system, creating outdoor spaces that respond to recreational needs, and providing reserve areas for the physical development of the campus and aesthetics (Irgatoğlu, 2011, 124). In addition, the squares, courtyards, and outdoor gathering areas between the buildings on the campus should be visible and accessible. Pedestrian paths should be safe and inviting, as well as allowing spontaneous interactions and a sense of community in line with the movement of people (Damugade et al., 2017, 157). In short, not only the buildings but also relations between buildings and the horizon line, viewpoint, roads, and edges should be designed as important plan inputs in campus design.

In a campus system, there should also be representation tools called campus landmarks that help make campus spaces more comprehensible. These components, which should be placed at 
Tuztașı, U., \& Koç, P. (2021). A spatial analysis of the physical properties of Sivas Cumhuriyet University Campus. Journal of Human Sciences, 18(4), 564-577. doi:10.14687/jhs.v18i4.6123

important points in the campus, add a unique value and historical-cultural connotations to the campus and stand out with their symbolic importance rather than their function (Yang, 2015, 1516). For a campus system, edges and borders also stand out as complementary physical components in the entire settlement. Edges are generally linear elements that are not perceived like roads. They act as a lateral reference and form the boundary separating the two types of areas (Lynch, 2010, 69). In a campus system, edges often occur around buildings or along with vehicle and pedestrian paths on the transportation axis. Of course, this does not mean that edges are a waste area, on the contrary, edges have distinctive, unifying, and directing properties. In this way, the edges help to perceive the transition from one area to another, visually, sensually, and intuitively, by referencing spatial and functional boundaries in a sense. Finally, it should be noted that the physical fabric of the campus can be renewed by adding new functions, new structures, and accessories to a campus system over time. Such articulations made in line with current needs and requirements should be realized through planned growth and development approaches for a campus. In this context, the growth models of the campuses are classified as a single-center, spontaneous growth, molecular growth, and linear growth (Irgatoğlu, 2011, 118). While growth and development models sometimes cause a campus system to move away from a holistic design, sometimes they can contribute to the continuity of the consistent relationship between components within the campus.

\subsection{Establishment of the Sivas Cumhuriyet University and location}

Sivas Cumhuriyet University was established in memory of the 50th anniversary of the foundation of the Republic, and 11,000 hectares of land were given to the university (Cumhuriyet University, 2021). The area reserved for the university is located $6 \mathrm{~km}$ away from the city center, on the Kayseri road (Figure 1). Cumhuriyet University, which began with the medical faculty in 1974, today consists of 18 faculties, 4 institutes, 1 state conservatory, 4 colleges, and 14 vocational schools (Cumhuriyet University, 2021) (Figure 1).
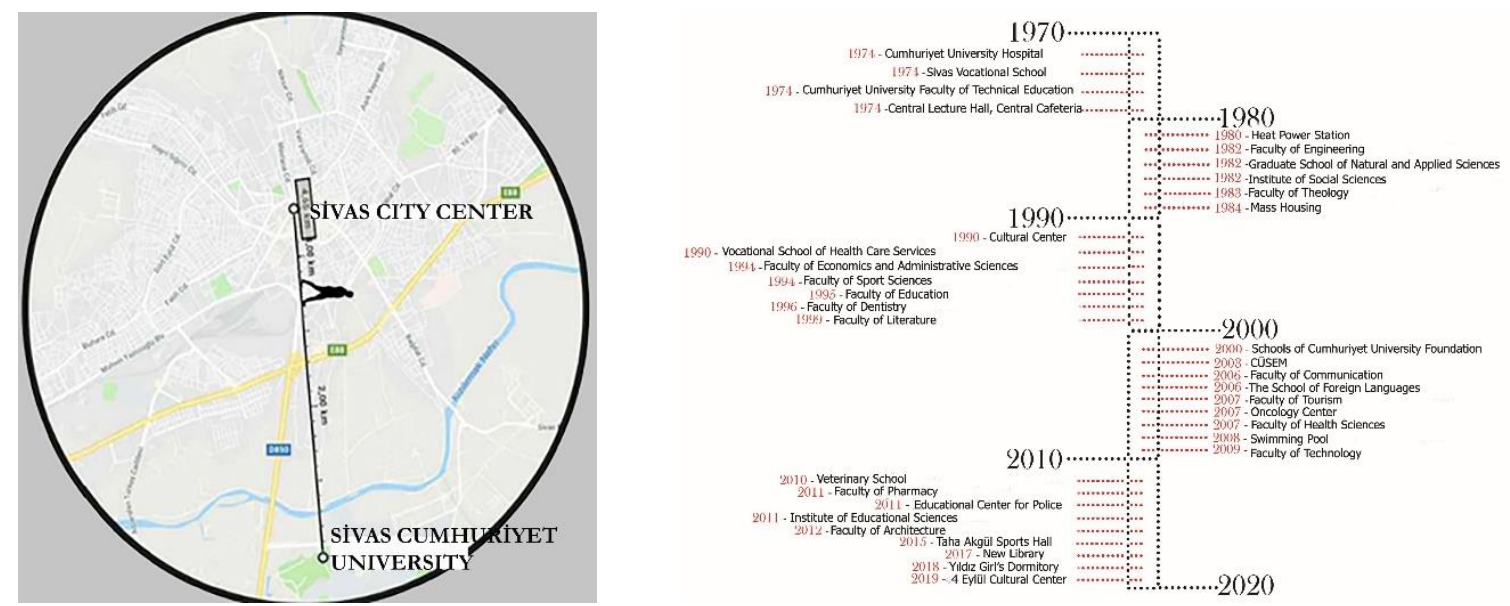

Figure 1. The location of the Sivas Cumhuriyet University in relation to the city center and a chronological development line of the university since 1970s.

The foundation of Cumhuriyet University was based on a meeting held in Sivas Chamber of Commerce and Industry in 1966. As a result of this meeting, which was held with the participation of different stakeholders in society, the way was opened for the establishment of an association that would establish the university (Işın, 2003, 10). The first meeting of the 4 Eylül University Foundation and Sustenance Association was held on 24 December 1967 in the Tuberculosis Dispensary Hall and a work plan was prepared (Işin, 2003, 11-13). The association was subsequently strengthened and accepted in the city with contributions from the employees of important public institutions such as the State Railway, the Sewing House, and the Regional Directorate of Highways, which were the result of the Republican modernization in Sivas. As a 
Tuztaş1, U., \& Koç, P. (2021). A spatial analysis of the physical properties of Sivas Cumhuriyet University Campus. Journal of Human Sciences, 18(4), 564-577. doi:10.14687/jhs.v18i4.6123

result, the university was established in 1973 with the law numbered 1701 and the name of the association was changed to "Cumhuriyet University Foundation and Protection Association" (Işsın, 2003, 23). The first faculty of the university was the Faculty of Medicine, and the university started teaching in the academic year of 1973-1974. The campus of the university was acquired as a result of various expropriation works, and the projects for the design of the faculty buildings were carried out by the Sisag firm. The construction of the buildings was put out to tender and secured by the Dilek Construction Company (Işıı, 2003, 56). It is understood that no holistic design study or comprehensive study plan was carried out for the university's campus at the beginning. The first faculty of medicine was established at the Chest Diseases Hospital, which was demolished in 2017. The top two floors of the 13-storey building were allocated to the hospital and the other floors to the medical faculty (Işin, 2003, 51). The medical school and practice hospital could only be moved to the building located on the campus, and whose foundation was laid in 1975, in 1992. This means that the buildings attached to the campus system were completed over a long period and, consequently, the settlement system is far from a holistic and consistent continuity design approach. Structures such as the old rectorate building built in 1976 or the indoor sports hall built in 1977 are distant from each other in terms of location, rational in terms of design qualities, but shaped similarly in terms of construction systems. Therefore, university buildings were initially of disconnected shapes and did not have a coherent campus appearance. In other words, a planned campus system and development could not be achieved under the conditions of the period. Instead, the construction of the university buildings and, thus, the development of the campus was achieved through the budgets from various initiatives. For example, in commemoration of the 50th anniversary of İs Bank a dormitory was built on the university campus on 10 November 1975 (Işın, 2003, 63). Finally, it is necessary to mention a previous study of the Cumhuriyet University campus. In this study by Tanrrverdi and Güçlü (1984) exemplary physical planning for the campus was undertaken. In line with the landscape analysis, five major fabrics were studied including campus education and management fabric, residential fabric, dormitory fabric, green structure and production fabric, and social and cultural recreation facilities (Irgatoğlu, 2011, 13). In this new study, which deals with the Cumhuriyet University Campus, the physical properties of the campus are examined through a field study.

\section{Purpose}

The purpose of this study is to reveal the physical properties of the Sivas Cumhuriyet University campus. In the architectural context, physical properties include the components of the built environment and enable the definition of the formal, sensory, and contextual contents of the composition in the axis of space organization. Physical properties also facilitate the comprehension and perception of the spatial organization, making the current state of the built environment an architectural information. Thus, a way to distinguish one spatial organization from another is found by comprehending the space in which it is located more easily. In addition, thanks to the up-to-date architectural information inventory of the built environment, the current situation can be reviewed and future improvements can be achieved within the scope of spatial organization. For these purposes, the Cumhuriyet University campus has been studied in terms of its physical properties.

The main purpose of this study is to obtain an architectural information about the built environment of the campus. In terms of the current scale and residential character of the campus, such a study also sees the Cumhuriyet University campus as a multi-component composition. A further objective of the study is to define the formal, sensory, and contextual contents of this multicomponent composition. Making use of the defined physical properties as a guide for future designs of the campus of Cumhuriyet University and presenting an architectural base for other studies to be carried out on the campus reveals the usefulness of the study. 
Tuztașı, U., \& Koç, P. (2021). A spatial analysis of the physical properties of Sivas Cumhuriyet University Campus. Journal of Human Sciences, 18(4), 564-577. doi:10.14687/jhs.v18i4.6123

\section{Method and material}

This study, which aims to reveal the physical properties of the Cumhuriyet University campus, basically determined the field study as a method. The method is based on fieldwork documentation tools such as observation, on-site examination, photography, and drawing. The study is presented in more detail in the following sections.

\subsection{The place and time of the study}

The place of study was the central campus of Sivas Cumhuriyet University. The field study was conducted in the fall semester of the 2019-2020 academic year.

\subsection{Population and sample selection}

Cumhuriyet University campus currently serves 48,270 students (Cumhuriyet University, 2021). The campus can be divided into four sub-regions: an academic area with educational and administrative units, a common area with social and cultural areas, a residential area where student dormitories are located, and a housing area where university faculty members are accommodated. In the field study, the accommodation zone and the housing zone were partially excluded because of the distance-related issues and center-periphery relations.

\subsection{Type of study, data collection method, and tools}

A field study was conducted to reveal the physical properties of the Cumhuriyet University campus. During the fieldwork, while the information gathering method and tools were based on documentation studies such as observation, on-site examination, and photography, archive documents were also used to collect data. Also, the layout plan and drawings of some projects obtained from the Department of Construction and Technical Affairs made it possible to make predictions between the current and future status of the campus. Finally, one of the data collection methods for analyzing the campus in terms of physical characteristics was developed from standard analysis tools used for urban space. Accordingly, boundaries were determined to collect data, build usage patterns and develop functional zoning maps. The development stages of the settlement in terms of morphology were determined and the balance of occupancy-vacancy was analyzed spatially. Data collection tools such as common areas and green areas were also used as rational analytical elements of the field study.

\subsection{Limitations and generalizability of the study}

The main factor limiting the study stems from the fact that a highly site-specific field study has been conducted. On the other hand, the fact that data collection tools have a common and general usage area makes the study generalizable. In addition, considering that university campuses are constantly evolving, it will not go unnoticed that the data constituting the study have some points that need to be constantly renewed rather than being a current reality. However, this study, which was carried out in a specific area at a certain time, will also be a basis for the future planning and development aspect of the campus, considering that the spatial change of university campuses is experienced as a slow and long-term process. Thus, the study will allow spatial comparisons and can be understood as a generalizable approach.

\section{Results and discussion}

Located $6 \mathrm{~km}$ away from Sivas city center, the Sivas Cumhuriyet University campus is insulated by Kizilirmak as a natural barrier from the city. Just as Kizilirmak surrounds the campus from the north side, there is another natural barrier in the south, a forest area. Thus, the campus, as a residential area, is in direct or indirect contact with urban space from the east and west directions. While a ring road to the west delimits the campus, a new developing urban space emerges in the easterly direction (Figure 2). The campus has a main entrance located on the ring road to the west. The medical faculty hospital can be reached directly through this main entrance. This means that 
Tuztaş1, U., \& Koç, P. (2021). A spatial analysis of the physical properties of Sivas Cumhuriyet University Campus. Journal of Human Sciences, 18(4), 564-577. doi:10.14687/jhs.v18i4.6123

the main entrance way of the campus and the linear line along this entrance axis have a permeable and fluid pattern due to healthcare services. This main axis also provides uninterrupted accessibility in the east-west direction. On the other hand, there are two entrance ways connected to this main axis on the campus and four entrance ways, one on the ring road and the other opening to the dormitory complex in the east. These entrance openings are shaped depending on the area where the campus is located and the density of users.

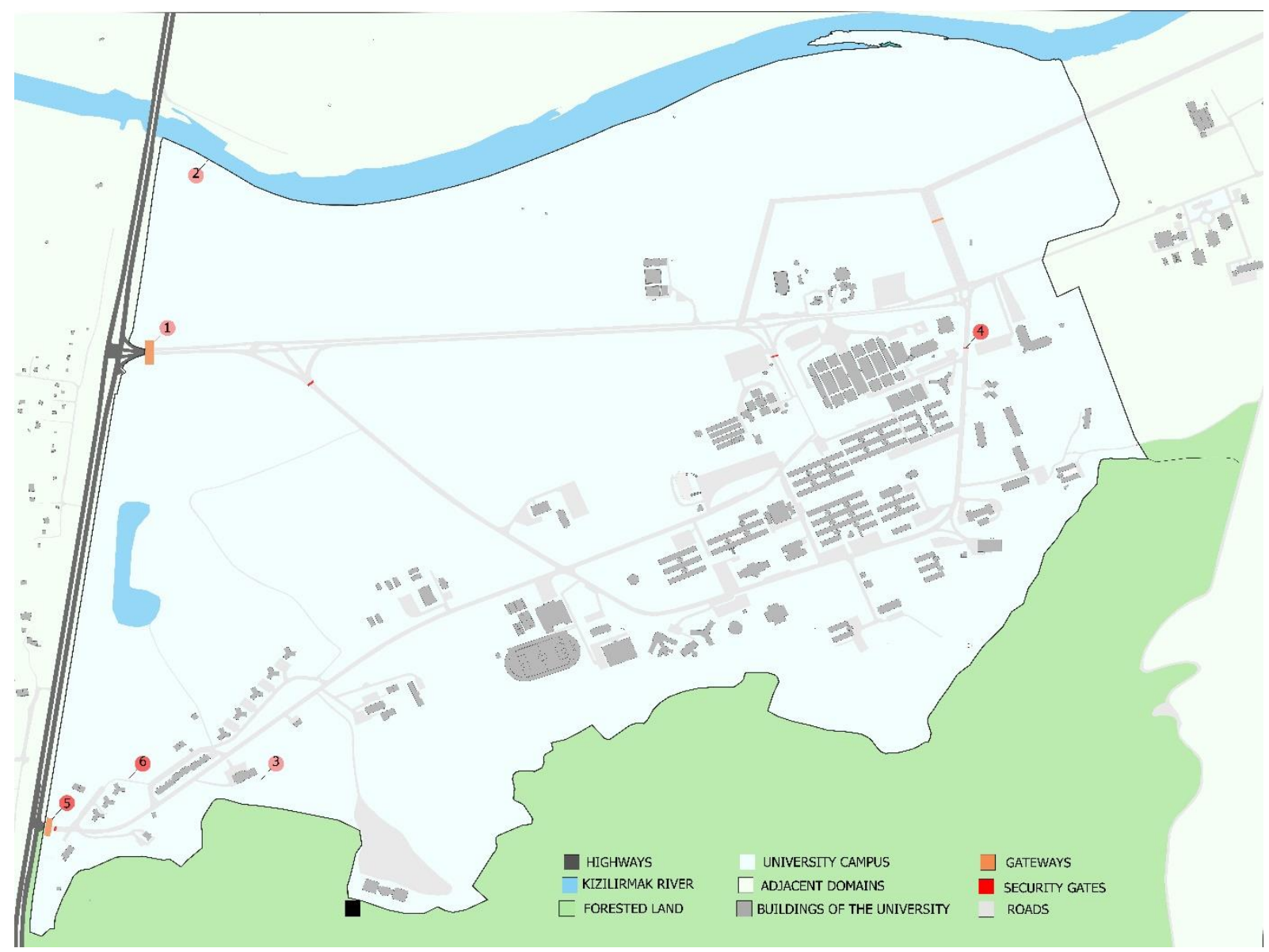

Figure 2. Campus and borders.

With the latest transportation planning, access to the campus is provided by the Kayseri-Sivas ring road, İsmet Yslmaz Boulevard, Erhan Üstündağ Street, and Recep Tayyip Erdoğan Boulevard. There is a circulation route that is predominantly shaped by the roads on the campus (Figure 3). Pedestrian paths are generally arranged as an axis running along the vehicle track. There are no long, wide pedestrian walkways. Access to all buildings is provided by the road and there is a parking arrangement in front of each building. However, this often negatively affects pedestrian access to buildings. The vehicle roads leading to the front of the buildings intersect with pedestrian paths and there is no separation between vehicle and pedestrian paths. Also, this destroys the entrance area of the building, making functions such as gathering-dispersion, aggregation, and lingering in front of the building difficult. Due to this dominance of the vehicle road, intense and constantly changing parking arrangements are made on the campus. This gradually causes open spaces to have a concreted appearance and decreases the density of green areas. 
Tuztaş1, U., \& Koç, P. (2021). A spatial analysis of the physical properties of Sivas Cumhuriyet University Campus. Journal of Human Sciences, 18(4), 564-577. doi:10.14687/jhs.v18i4.6123

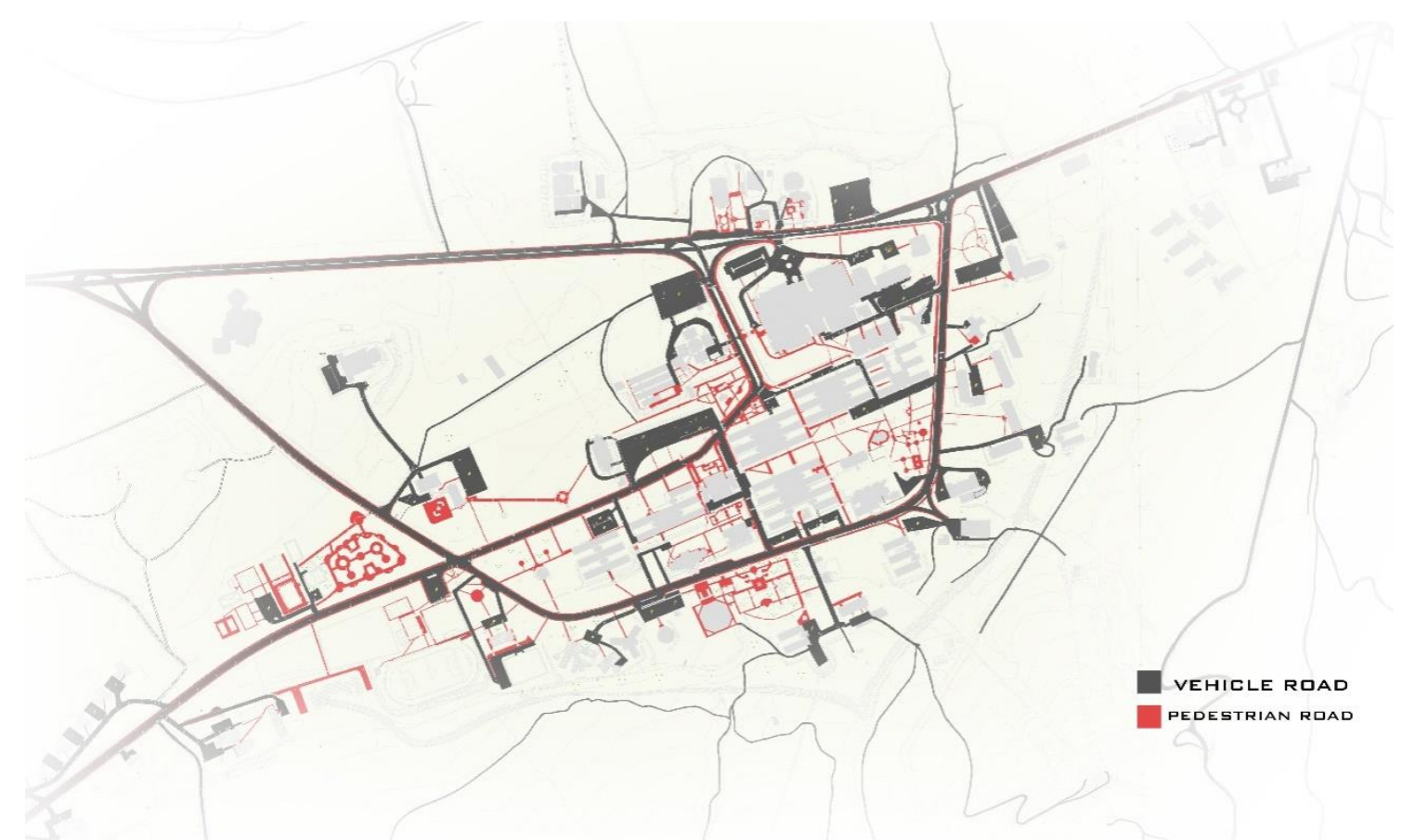

Figure 3. Vehicle road and pedestrian path analysis on campus.

When the Sivas Cumhuriyet University campus is viewed from the upper scale, it has a residential character similar to the widespread type of settlement system in which there is a random distribution of individual buildings in a natural park without being affected by topographic conditions. In this system, there is a second center with a sparse building density and the common areas appear as large empty spaces (Büyükşahin Sıramkaya \& Çıınar, 2012, 63). Some detailed research has analyzed the widespread type scheme of the campus settlement of Sivas Cumhuriyet University. Accordingly, it is the area that constitutes the core of the campus and includes the first regional medical school and hospital, and the faculties of engineering, science, and literature, which were the first faculty buildings of the university. The design and construction features of the buildings in this area all have similar characteristics. In this way, it can be stated that the campus was initially built with a linear system. However, there are also areas where this linear system forming the core region differs in terms of both layout character and design and construction. For example, although the dormitory built by İs Bank, the central cafeteria, old library, staff cafeteria, and central amphitheater are located in the core region and some of them show similarities, they differ from the linear system in terms of location, design, and construction features. These differences have deepened over time and, as a result of the growth of the campus area, new development areas that are completely different in terms of design and construction features have emerged. To understand this situation better, occupancy-vacancy analysis, building use analysis, and morphological analysis were carried out within the campus system.

The occupancy-vacancy analysis was performed to emphasize the balance between the structures in the campus and the remaining spaces. The occupancy-vacancy ratio, starting from the core region, also revealed the development direction of the campus (Figure 4). Accordingly, the region defined as the core area (area I) has the highest density in terms of structuring. The area II, which is attached to the southeast of the campus and contains some faculty buildings and some service units such as a heating center and workshop, has emerged as the secondary development area of the campus. The third direction of development is the area III articulated to the southwest of the core region and surrounded by sports fields and lodgings. The low rate of construction of the third zone is due to the use of this area for recreation, sports, and accommodation and its proximity to the forest area, which is the natural barrier of the campus. On the other hand, the areas marked with numbers IV and V in the settlement system of the campus have recently been 
opened to construction and it seems that the occupancy rate will increase rapidly. Starting from area III, new faculty buildings are being built in areas with low settlement rates. It is difficult to say that these new buildings were built by a plan that takes into account the holistic system of the campus because each building has its own singular character and unique environment. In this state, new buildings are added to the campus system, but cannot be integrated into the campus as a holistic and consistent design practice. In the meantime, it should be noted that the first buildings that formed the core area are now gradually under demolition due to various requirements and new structures are being built in their place that will disrupt the design characteristics of the core region. It could be said that the settlement system in the campus, where the occupancy-vacancy balance is gradually deteriorating in favor of occupancy, has gradually gained a new appearance with undefined vacancy, singular design practice, and buildings built on larger scales.

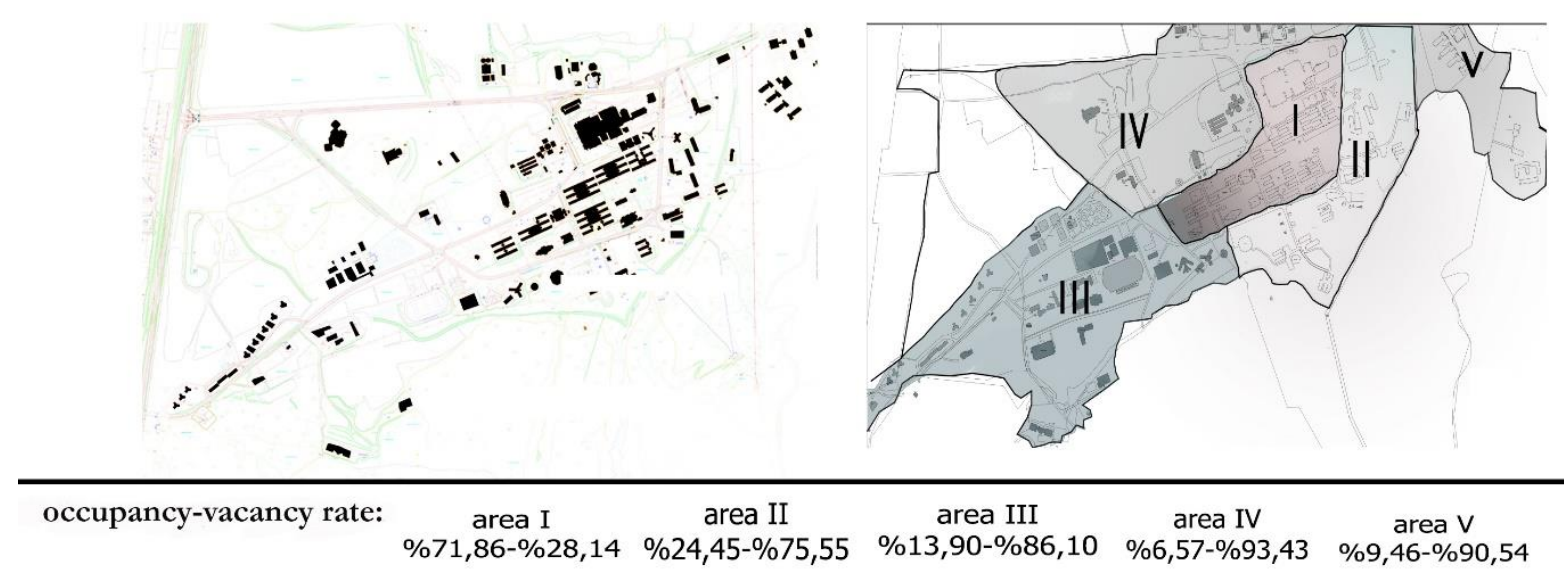

Figure 4. Campus occupancy-vacancy analysis.

Building use analysis reveals the functional separation of the structures that create the occupancy-vacancy balance. It should also be stated at this point that the core region represents the most functionally dense area. The new buildings, starting from the third region (area III) and spreading over time to the area IV and the area V, emerged either as new buildings of the old faculties detached from the core region or as buildings of the newly established faculties or closed common areas (Figure 5). 
Tuztaş1, U., \& Koç, P. (2021). A spatial analysis of the physical properties of Sivas Cumhuriyet University Campus. Journal of Human Sciences, 18(4), 564-577. doi:10.14687/jhs.v18i4.6123

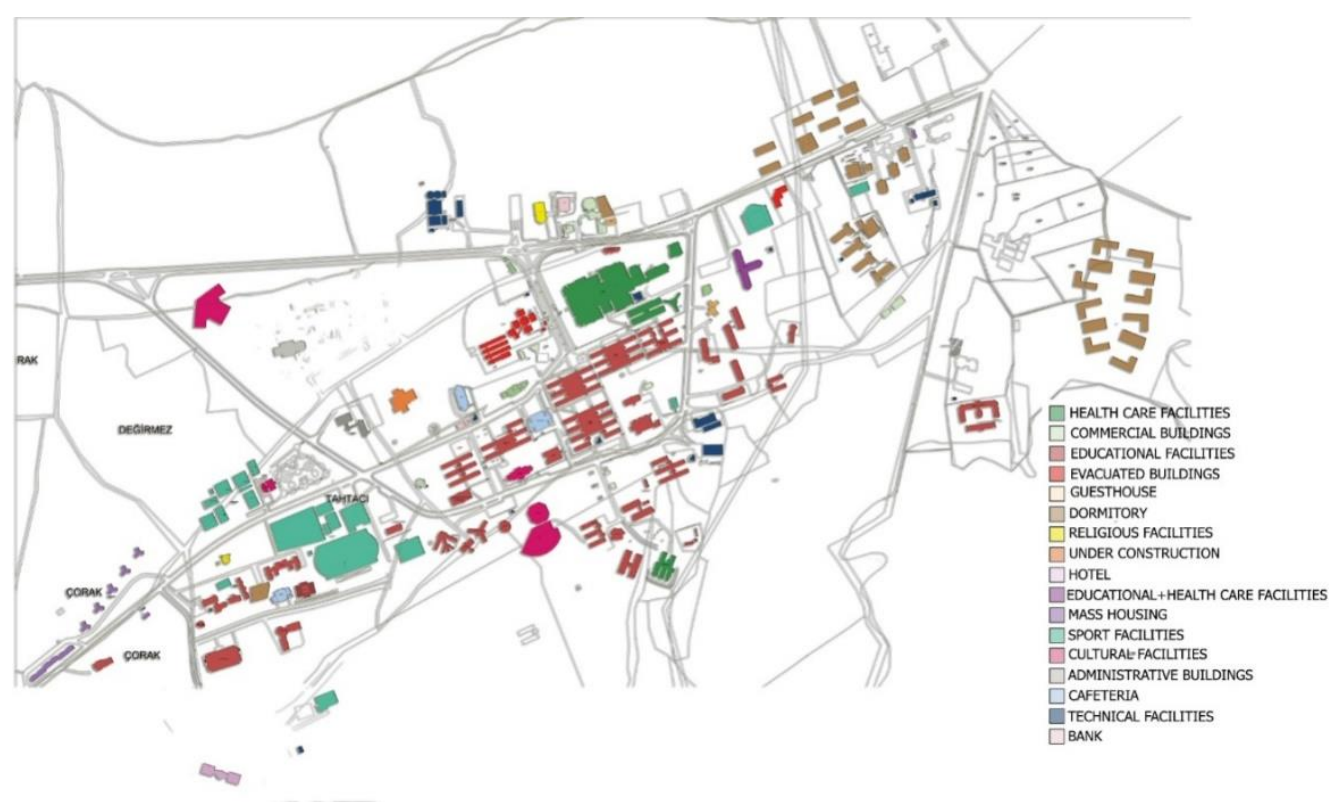

Figure 5. Building use analysis in Campus.

Morphological analysis performed to understand the formation language of the settlement pattern in the campus presents a much more diversified fabric (Figure 6). Although the general settlement pattern of the campus is a widespread type of settlement system, considering the regions that make up the settlement pattern, it becomes clear that the shaping language of the campus is extremely complex. For example, in the occupancy-vacancy analysis, the buildings are positioned with a linear organization in the area marked with the number 1 and declared as the core region of the campus. The initial rational construction system brought rational form and positioning with it; however, the buildings were scattered in the same area, which over time separated from the linear shaping language and settled freely in the spaces in the area. If we move away from this core region and examine the later developing regions of the campus, there is a formal discrepancy between this first region and the later development regions. In the settlement system, the areas outside the core region are completely formed as free and scattered within themselves. Just as there is no coherent and holistic plan pattern attached to the core region, these later developed regions do not exhibit a consistent and holistic understanding of design. Free-standing cluster organizations have emerged in these areas. The shaping language is shaped by a scattered cluster, axial cluster, and radial cluster organization. Each building is positioned in a free order and as a singular pattern, with some later open space arrangements between the buildings; building groups are clustered scattered, axially or radially. It is revealed that the general view of the campus lacks a coherent and holistic plan or understanding, and the general view consists of free-standing individual buildings through the structures that are later articulated in the widespread type settlement system. Consequently, the balance of occupancy-vacancy and open space in the campus has been shaped by a very fragile and disconnected relationship. The free positioning, orientation, and formation of individual buildings makes it difficult to perceive the settlement as a landscape pattern (Figure 7). 


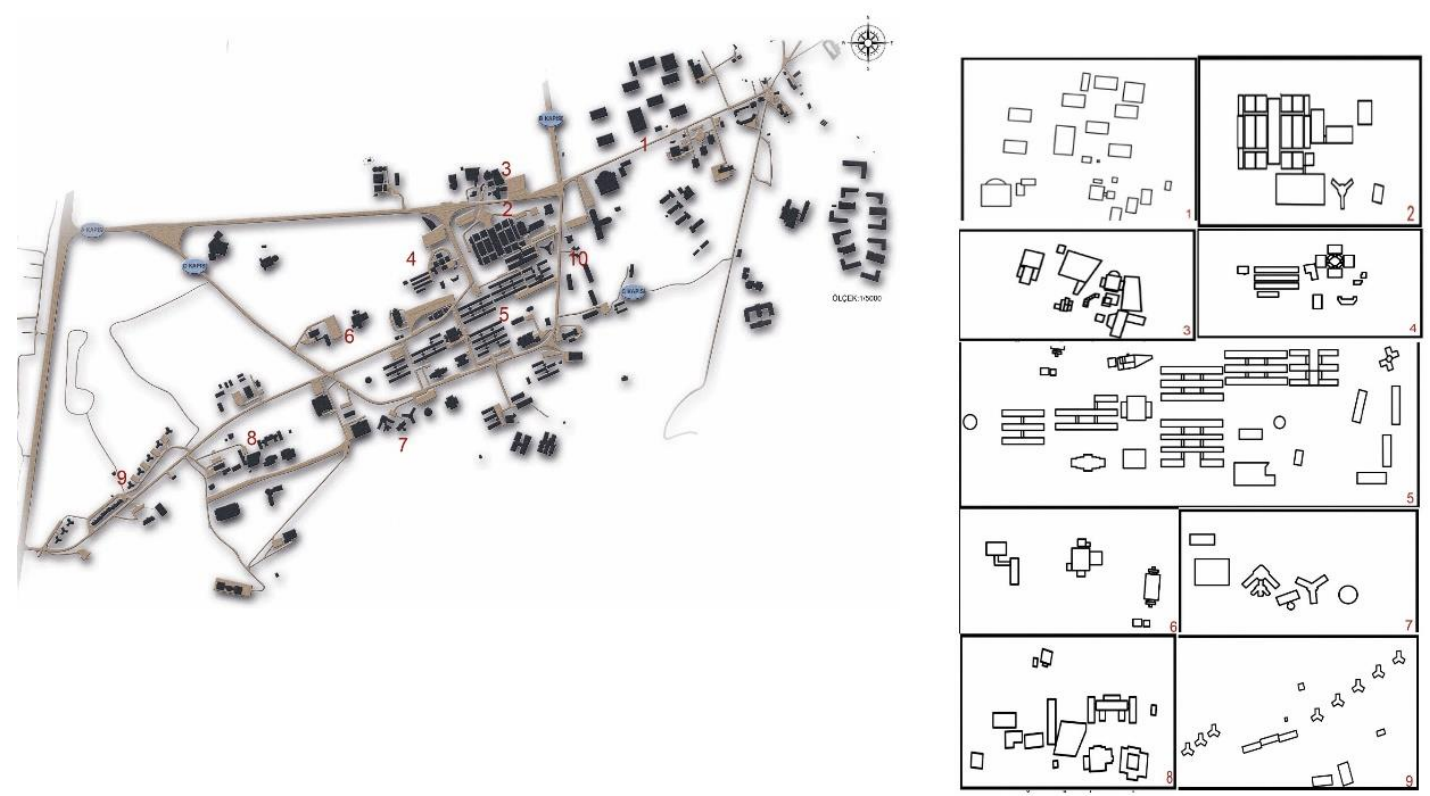

Figure 6. Morphological analysis of campus.
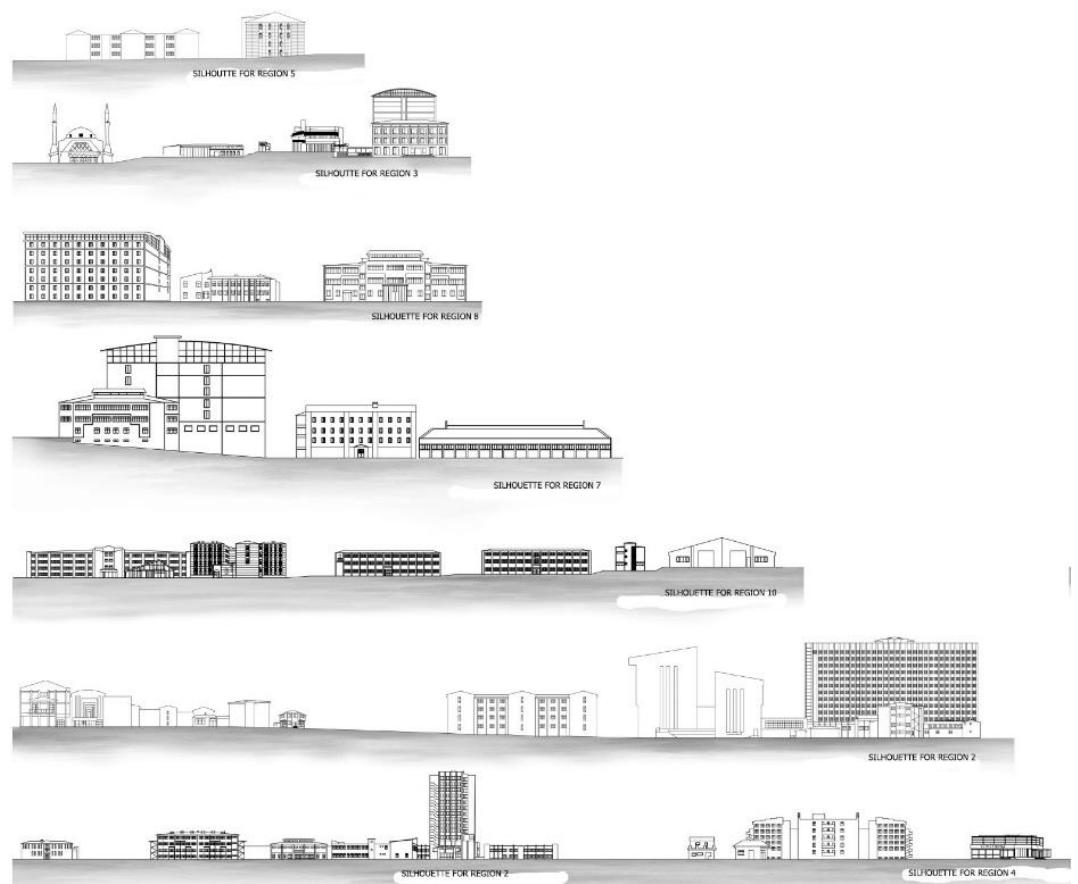

Figure 7. Views of the settlement pattern in the campus.

This scattered and free fabric of the settlement language, of course, directly affects the distribution of common areas and green areas on the campus. Common areas are places that can be used by different groups such as cafeterias, staff cafeteria, libraries, sport areas other than administrative and educational buildings, as well as open and closed spaces. Accordingly, the campus consists of common areas, green spaces, housing, trade, health, culture, sports, and prayer spaces (Figure 8). These spaces, which make up the common areas, are scattered in terms of location and placed in a free and singular manner in terms of the language of formation. Green areas on the campus consist of areas between the buildings. The landscaping of the buildings standing free and singular in the settlement creates the active and passive green areas of the campus (Figure 8). Only the spaces between the buildings in the first settlement area, which is described as 
Tuztaşı, U., \& Koç, P. (2021). A spatial analysis of the physical properties of Sivas Cumhuriyet University Campus. Journal of Human Sciences, 18(4), 564-577. doi:10.14687/jhs.v18i4.6123

the core region, look like a regular open green area. During this period, large park areas were also articulated to the campus in several different locations and forms. Although these park areas have also emerged with the evaluation of the remaining spaces from the buildings, they have gradually become dysfunctional and desolate during the development stages of the campus. In short, there is no place that we can call an active green area on the campus; all green areas have a passive recreational appearance. On the other hand, demolition and reconstruction processes during the development stages have led to the emergence of residual areas on the campus. In other words, the areas left over from the buildings emerge as either passive green areas or residual areas.

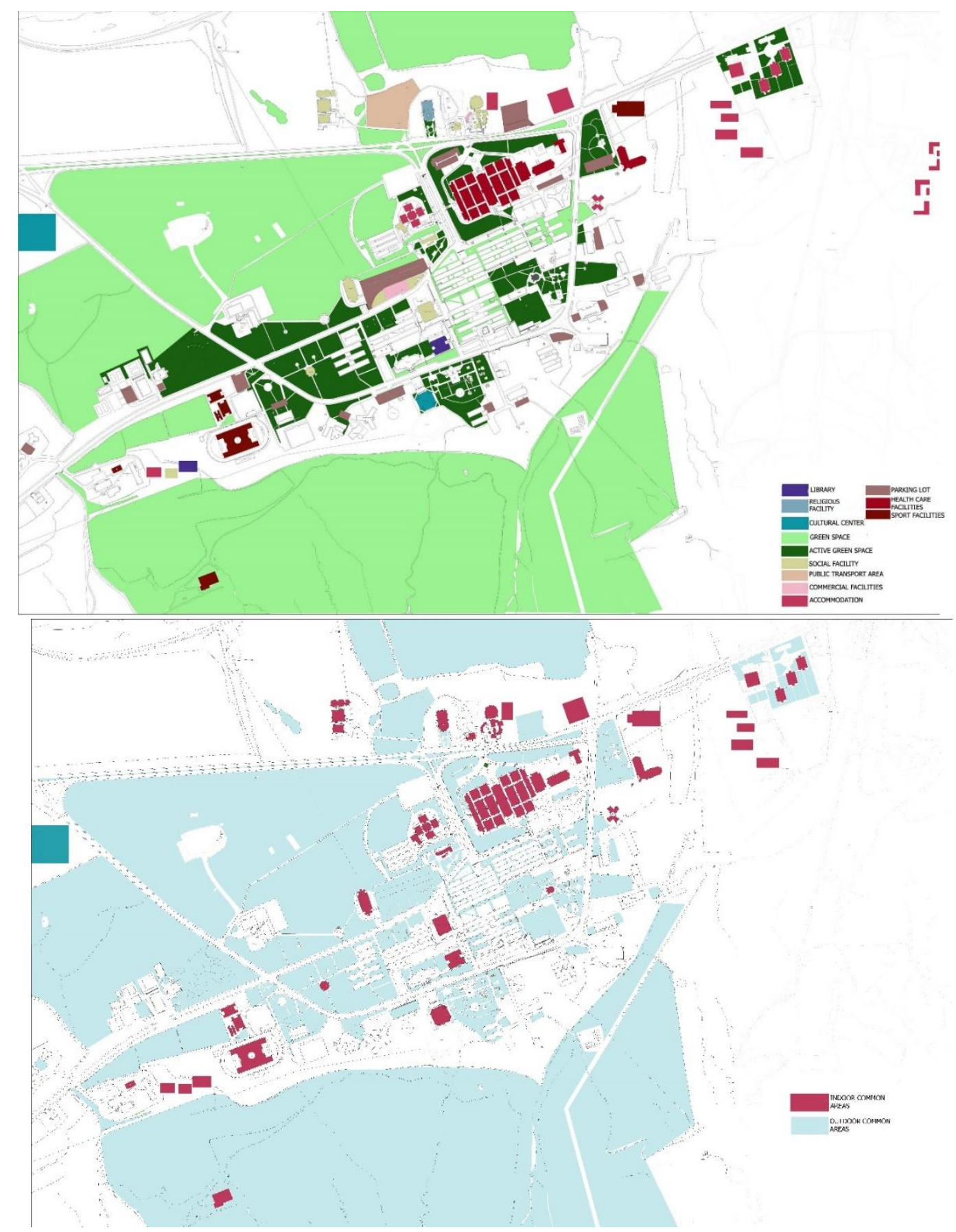

Figure 8. Common area analysis of campus. 
Tuztaş1, U., \& Koç, P. (2021). A spatial analysis of the physical properties of Sivas Cumhuriyet University Campus. Journal of Human Sciences, 18(4), 564-577. doi:10.14687/jhs.v18i4.6123

\section{Conclusion and recommendation}

This study analyzed the physical properties of the Sivas Cumhuriyet University campus and the spatial characteristics of the built environment. In line with this analysis, boundaries and building usage patterns were determined. The development stages of the settlement were determined in terms of morphology and the balance of occupancy-vacancy was analyzed spatially. Data collection tools such as common areas and green areas were also used as rational analytical elements of the field study. From the point of literature review, it is primarily revealed that landscape pattern of the Cumhuriyet University campus cannot be directly defined because of the random distribution. Although the campus had a linear type of settlement language initially, it transformed into a widespread type due to the scattered and free practices. However, common areas such as educational, administrative and recreational facilities remain constant or idle. In addition, outdoor spaces in the campus were determined by occupancy-vacancy and common area analysis. According to the literature review, common areas and outdoor spaces in a campus should provide coherent and holistic relationships in terms of planning stages of a campus. However, the findings indicated that not only outdoor spaces but also common areas in the Cumhuriyet University campus were characterized by disconnected relationships. These spaces were built in accordance with the development direction of the campus rather than a holistic design approach.

In terms of access and borders of the campus, changes in recent years occurred rapidly. The ring road to the west of the Sivas Cumhuriyet University campus is in direct contact with the urban space from the east due to Kizllirmak to the north and the forest area to the south. The urban space to the east is a newly developing area of the city. Due to its proximity to the university, this area develops mostly through spatial facilities such as dormitories and hostels where housing and commercial activities take place. Therefore, this area is the most important factor limiting the development potential of the campus in the eastern direction and, accordingly, the campus has development and growth potential in the wide area in which it is located.

Transportation to the campus is provided via Kayseri-Sivas ring road, İsmet Yllmaz Boulevard, Erhan Üstündağ Street, and Recep Tayyip Erdoğan Boulevard. The in-campus transportation system is predominantly structured in favor of vehicle traffic. Car parks and secondary roads opening to all buildings are connected to the main road network on the campus. Pedestrians on the campus move on the sidewalks formed along the roadways. Long walkways or pedestrian-only roads are not present on the campus, and the vehicle paths extend to the building entrances. This leads to the intersection of pedestrian-vehicle traffic and the disappearance of a defining entrance space in the exterior of the buildings.

The campus can be divided into five areas as a development orientation. The first area is the part of the campus composed of structures such as medicine and engineering faculties and called the core region in the article. Other areas are regions articulated to this core area. Since the construction process of the regions does not involve a sequential order, it can be said that the balance of occupancy-vacancy deteriorates as the campus opens to construction. The spaces between the structures built separately and disconnected from each other have been structured in line with the individual and independent decisions taken over time. This shows that the settlement system is far from holistic in its planning principles.

The lack of a holistic design approach has caused the campus's shaping language to be heterogeneous and unrelated. Despite the first consistent formal language that emerged with the linear organization of the core area, other areas have been shaped by cluster organizations that do not show any formal consistency and continuity with each other. Although this reveals a variety in terms of form language, it has transformed the general characteristics of the settlement into a scattered and fragmented perceptual level. Thus, the common areas and green areas on the campus have been fragmented and gradually become dysfunctional and desolate while disappearing into a disconnected built environment. Moreover, these spaces have become a potential construction site for new buildings. 
Tuztașı, U., \& Koç, P. (2021). A spatial analysis of the physical properties of Sivas Cumhuriyet University Campus. Journal of Human Sciences, 18(4), 564-577. doi:10.14687/jhs.v18i4.6123

In conclusion, this study, which analyzed the current physical environment of the campus, proposes the preparation of an urgent design guide for the campus. Built environmental components that have hitherto been disconnected, dispersed, fragmented, and unrelated can be repaired through spatial organizations that are holistic, consistent, and continuous. This will automatically resolve the use of common areas, active-passive green areas, and vehicle-pedestrian balance on the campus.

References
$\mathrm{Ak}$, S. (2007). Üniversite kampüslerinde tasarm kriterlerinin ve yerleșim sistemlerinin büyüme ve gelisme olanaklar bağlamında irdelenmesi (Yayımlanmamış Yüksek Lisans Tezi), Yıldız Teknik Üniversitesi.

Aydin, D. \& Ter, U. (2008). Outdoor space quality: Case study of a university campus plaza. Archnet-IJAR, International Journal of Architectural Research, 2(3), 189-203.

Büyükşahin Sıramkaya, S. \& Çınar, K. (2012). Üniversite kampüs yerleşkelerinde ortak kullanım mekanlarının incelenmesi: Selçuk üniversitesi alâeddin keykubat kampüsü örneği. S.Ü. Müh.Mim. Fak. Dergisi, 27(3), 61-72.

Cumhuriyet Üniversitesi. (2021). Genel Tantım. Retrieved January, 1, 2021, from https://www.cumhuriyet.edu.tr/genel-tanitim

Çiçek Kurdoğlu, B., Yurdakul, N. M. \& Bayramoğlu, E. (2018). Yeşil kampüs yaklaşımının uzman değerlendirme yöntemi ile incelenmesi. Social Sciences Studies Journal, 4(19), 2064-2071.

Damugade, S. Y., Damugade, Y. N. \& Pingale, T. B. (2017). Campus planning. International Journal of Engineering Research and Technology, 10(1), 156-158.

Düzenli T., Mumcu, S. \& Akyol, D. (2017). Üniversite kampüsü açık mekanlarının gençler tarafindan kullanım amaçlarının belirlenmesi. Uluslararası Sosyal Araştırmalar Dergisi, 10(49), 766-772.

Erçevik, B. \& Önal, F. (2011). Üniversite kampüs sistemlerinde sosyal mekan kullanımları. Megaron, 6(3), 151-161.

Göçer, Ö., Özbil Torun, A. \& Bakoviç, M. (2018). Kent dışı bir üniversite kampüsünün dış mekanlannda 1sil konfor, kullanım ve mekan dizim analizi. Journal of the Faculty of Engineering Architecture of Gari University, 33(3), 853-873.

Gümüş, İ., (2020). Üniversite-kent etkileşiminde melez "üçüncü mekan” kavramı doğrultusunda "rizomatik kampüs yerleşim sistemi modeli" önerisi. Online Journal of Art and Design, 8(2), 208-224.

Irgatoğlu, A. N. (2011). Üniversite Kampuslar Fizilesel ve Gelişim Planlaması ve Tasarmı: Yozgat Bozok Üniversitesi Erdoğan Akdă̆ Kampusu Örneği (Yayımlanmamış Yüksek Lisans Tezi), Ankara Üniversitesi.

Işın, R. (2003). Cumburiyet Üniversitesi Kuruluş Calışmalar. İkinci Baskı. Sivas: Önder Matbaacılık.

Lau, S. S. Y., Gou, Z. \& Liu, Y. (2014). Healthy campus by open space design: Approaches and guidelines. Frontiers of Architectural Research, 3, 452-467.

Lynch, K. (2010). Kent imgesi. Trans. İ. Başaran. İstanbul: Türkiye İş Bankası Kültür Yayınları.

Sönmezler, K. (2003). Modern Mimarinin Kentsel Deney Alanı: Üniversite Tasarmı (Yayımlanmamış Doktora Tezi), Mimar Sinan Güzel Sanatlar Üniversitesi.

Tanriverdi, F. \& Güçlü, K. (1984). Cumhuriyet üniversitesi kampüs peyzaj planlama ve uygulama prensipleri üzerine bir araştırma. Cumburiyet Üniversitesi Fen Bilimleri Dergisi, 2, 13-29.

Yang, S. (2015). The research on the design concept of the campus planning of national Taiwan university-Taking National Kaohsiung First University of scienceand technology as an example. Proceedings of International Symposium on Social Science. Retrieved from https://www.atlantis-press.com/proceedings/isss-15/23977

Yorgancıoğlu, D., Tunalı, S., Çetinel, M., Kırdar, G. \& Aşık, M. A. (2018). Üniversite kampüsünün mekan ve pedagoji ilişkisi bağlamında değerlendirilmesi. Yükesekögretim ve Bilim Dergisi, 8(2), 314-326. 